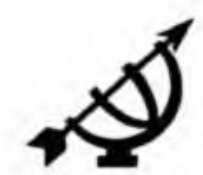

\title{
Parents as partners in black schools: so important, but why so unreliable?
}

\author{
J. Heystek \\ Department of Education Management \\ University of Pretoria \\ PRETORIA \\ E mail: jheystek@hakuna.up.ac.za
}

\begin{abstract}
Parents as partners in black schools: so important, but why so unreliable?

Parents and schools are partners in the education of children because schools are a formalised extension of the family, when it comes to the education of children. This partnership is also emphasised by recent legislation, like the South African Schools Act of 1996. This partnership is in line with the mission of parents to educate their children or assist in the education of their children. In spite of this demand for parental involvement in schools, the research in black schools underlying this article indicates that parental involvement in most black school activities is limited. Reasons like a negative attitude of parents towards schools and feelings of inferiority prevents parents to become effective partners of schools. The reasons for the lack of active participation in school activities and some possible solutions will receive attention in this contribution.
\end{abstract}

\section{Introduction}

Parents constitute one of the possible partners of schools. Other partners are the national and provincial departments of education, foreign governments and organisations, the community, businesses and non-governmental organisations. This article, however, focuses on parents as very important partners for schools, in view of the fact that the South African Schools Act of 1996 identifies parents as the official partners in the governance of their children's school. In accordance with this Act, parents constitute the majority of the members in the governing body of a school.

The principle underlying this partnership is the fact that the family is the primary educating structure for children. Although it may not have been the intention of the government to promote Christian principles, the new legislation is in line 
with Christian principles, which stipulate that it is part of the mission of parents to be involved in the education of their children. The child's basic right implies that parents accept a particular responsibility for the well-being of the child, his care, protection and safety, his becoming and growth towards adulthood, as a God-given responsibility. Schools and parents must therefore co-operate closely when it comes to the education of children. Schools are a formalised extension of the family and according to Van der Walt (1992:226) and Wolfendale (1992:32) schools therefore need to adhere to the same norms and values as the family. This view is in line with the theory of Epstein (1996:6), who argues that if the school, the parents and the external community all have the same goals for children, they will most probably succeed in achieving such goals. Van der Walt (1992:228) indicates that children are members of all societal structures, namely the family, school, the church. A partnership, based on the same mutual values, norms and goals, will therefore improve the relationship between schools and families. This partnership is most visible in the governance structure of schools where parents and the school staff manage the school together.

According to Sund (1976:60-61) Piaget indicated that parents and the community environment in which the child grows up, are very important elements in the cognitive development of the child. This statement correlates with the findings of Khan (1996:59), namely that parental participation in school activities and parents' assistance with their children's homework can improve both the academic achievement of children as well as the relationship between home and school. According to Schoeman (1980:105) the main reason for parents to be involved in school activities is to ensure that the norms and values of schools are in accordance to the norms and values of the parents and the same norms that the children experience at home. It may be traumatic for children if a difference exists between the values at homes and the values in school. This may influence the academic work of children (Schoeman, 1980:100). This aspect provides two important reasons why parents should be involved in school activities.

Children grow up in a community characterised by a specific culture and specific values. Through their involvement, parents must ensure that the formal education offered at the school and attended by their children, is in line with their own values and culture (Henning \& Fourie, 1997:121). Therefore, if parents are not involved, they cannot blame the school for not conforming to the values and culture of the community. According to Van der Westhuizen (1996:29), a successful home-school partnership requires that school activities be directly linked to the values and norms of the parents and the community. Parents must be partners and participate in school activities in order to ensure that their values and culture are maintained and promoted in the school.

South African parents have had different experiences of their participation in school activities. Parents of previous Model C schools were used to a powerful 
governing body managing their school. In contrast, the parents of most previous blacks-only schools have had little or no experience of management or participation in their schools. Although black parents have traditionally been involved in the education of their children, according to their local needs and norms, the traditional westernised school system has not been part of the reference frame work of black parents (Mavhiva, 1996:68). As indicated in this article, black parents do not see the school and the education of their children as their responsibility.

In the past parents were predominantly involved with the governance of schools only, despite the fact that there actually are numerous activities in which parents can be involved. Such involvement may occur at different levels, ranging from assisting children with their homework and assisting teachers, to the official management of schools (Khan, 1996:61).

In terms of the South African Schools Act of 1996, parents are legally bound to be involved in the governance of their children's schools. Parents must use this opportunity to determine the norms and values of the schools, for example by determining the language and religious policy of the school. Other forms of participation are voluntary, and schools and parents must be motivated and trained to engage in worthwhile partnerships. Participation in activities such as fundraising, assisting teachers with academic or extramural activities, and motivating their children to perform well in school, depend on the extent to which such involvement is encouraged by the school and the principal. Parental involvement must not only be motivated by legislation, but by the mission of parents to be part of the education of their children

This article aims to

- indicate that parents are obliged to participate in the education of their children because it is part of their mission;

- determine the extent to which black parents are actively involved as partners in school activities;

- establish the reasons why black parents are not actively involved in school activities, and

- assist educational practitioners to improve parental participation in schools so as to improve the quality of education in schools. 


\section{Definition of concepts}

\subsection{Parents}

For the purposes of this article parents are defined as adults who have children in a specific school. These adults may be either the biological parents, guardians or caretakers of these children. What is, however, important is that the parents must be those who are responsible for the child and who must and can be involved in the school's activities.

\subsection{Partners}

The relationship between parents and schools has changed from a client-type to a partnership-type relationship. This partnership indicates that parents are part of the decision-making processes and the implementation of it in schools. Ideally, parents and teachers should have an equal mandate and expertise, contribute and receive services on equal footing and share responsibility and accountability for a high standard of education in schools (Khan, 1996:60). It is important that teachers and parents share the same goals, respect one another, and share information, responsibility and accountability if this partnership is to be a success (Wolfendale, 1992:14). The ideal situation is that teachers and parents as partners should have the same norms and values (Van der Walt et al., 1983:263). This situation will make it easier to determine and achieve goals for the school

\section{Research}

An empirical research project was conducted in the previously black-only schools to determine the level of parental participation in school activities. The research instrument used was a structured English-medium questionnaire, which was divided into the following three sections:

- The ratio of parental participation in specified school activities

- The reasons for black parents' lack of active involvement in school activities

- Possible solutions for improving parental participation in school activities

The respondents were free to provide additional answers at every section.

Although the universum population consisted of the teachers in the previously blacks-only schools in the Northern Province, Mpumalanga, North West Province and Gauteng, two hundred respondents randomly selected acted as the actual sample. The sample adequately represented the possible population because all the possible types of schools and different post levels of teachers were included in the sample. 
The research and the interpretation were done from a school management perspective. Although only teachers completed the questionnaires, they were able and capable to provide the required information. The teachers could determine the ratio of parental involvement in school activities. The teachers in the research project were experienced teachers (Heystek, 1998), and therefore the reasons they provided for the low involvement of parents were acceptable, because the teachers knew the parents and there situations well. Only a few questions in section 2 of the questionnaire (the reasons why parents are not actively involved in school activities) required of the teachers to indicate the feelings or attitudes of the parents. Parents were not involved in the first phase of this research project because of practical, logistical and language problems.

\section{Parental participation in school activities}

The aim of this article is to determine the degree of parental participation in specific school activities. The statistics indicate the percentages of parental participation in the activities concerned.

Parental participation was divided into the following three categories:

- No activity. This category indicates that the school does not make provision for any activity in which parents may get involved.

- Little participation. Parents do participate in school activities, but they are not very active.

- Good participation. This category denotes that parents participate actively and contribute positively to the school's activities.

\subsection{School management activities}

\section{Table 1: School management activities}

\begin{tabular}{|l|l|l|l|}
\hline & No activity & $\begin{array}{l}\text { Little } \\
\text { participation }\end{array}$ & Good participation \\
\hline \hline Governing body & $4,0 \%$ & $38,0 \%$ & $57,9 \%$ \\
\hline Parent-teacher association & $23,0 \%$ & $35,8 \%$ & $41,2 \%$ \\
\hline $\begin{array}{l}\text { Parent-teacher-student } \\
\text { association }\end{array}$ & $40,1 \%$ & $33,6 \%$ & $26,4 \%$ \\
\hline
\end{tabular}


Parents as partners in black schools: so important, but why so unrellable?

\subsubsection{Findings}

The above is the only category of activities in which good participation recorded the highest percentage. Despite the fact that these statistics point to good participation in the activities of the governing bodies and parent-teacher associations, it was alarming to note that - though not many - there are schools that still do not have a governing body. In terms of current legislation all schools should have had established governing bodies - already by the end of 1997.

The statistics relating to parent-teacher-student associations indicate that most of the schools did not have such a structure in which to involve parents. Although good participation was recorded in some schools, the parent-teacher-student association is one structure that can be implemented by most schools - a structure which will improve the participation of parents

This is an important area for parents because the three mentioned structures will determine the norms and values of the school. If parents are not actively involved in these structures, they will neglect their mission as parents in the education of their children.

\subsubsection{Recommendations}

Since the number of schools that do not have a parent-teacher association is too high, it is recommended that all schools establish such an association. In these structures it is possible for teachers and parents to work together in specific areas not related to academic work. Extramural activities, fundraising and other social events can be organised by the parent-teacher association, and it can also serve as an informal structure where teachers and parents have the opportunity to get to know one another. This improved relationship can be transferred to the academic work and can contribute to improve the standard of learning and teaching in the school.

\subsection{Teaching and education}

Table 2: Teaching and education

\begin{tabular}{|l|l|l|l|}
\hline & No activity & $\begin{array}{l}\text { Little } \\
\text { participation }\end{array}$ & $\begin{array}{l}\text { Good } \\
\text { participation }\end{array}$ \\
\hline $\begin{array}{l}\text { Act as assistant for teachers in } \\
\text { the class }\end{array}$ & $50,9 \%$ & $35,5 \%$ & $13,7 \%$ \\
\hline $\begin{array}{l}\text { Assist in collecting study } \\
\text { materials }\end{array}$ & $48,9 \%$ & $35,8 \%$ & $15,3 \%$ \\
\hline Assist learners with homework & $18,0 \%$ & $68,0 \%$ & $14,1 \%$ \\
\hline
\end{tabular}




\subsubsection{Findings}

According to the research undertaken this was the worst area as far as parental participation in school activities was concerned. In most of the schools involved in the research, no provision whatsoever was made for parents to be involved in the teaching and education of their children. Parents did not have the opportunity to become involved in these activities because no structures or planning existed to accommodate these activities. The findings also implied that parents could not participate in these activities even if they wished to do so, and that schools did not create the opportunity for parents to be actively involved with their teaching activities.

It should, however, also be remembered that parental participation in the different school activities do not necessarily improve the childrens' academic achievements. The fact that a child's parent is a member of the governing structure of the school will not necessarily improve his/her academic achievement. In fact, a parent who is interested in his child's work and who assists him/her with homework (Epstein, 1996:10) will rather improve academic achievement

\subsubsection{Recommendations}

The participation of parents in the teaching and education of their children is the one area that needs the biggest improvement as far as the potential participation of parents is concerned. It is probably the most important area for parental involvement in schools because teaching and educating learners constitutes the main aim of all schools. Although many parents exclusively rely on teachers to perform this task, they themselves must also be involved in this activity. It should be a priority for schools to improve this area of parental participation, as this would undoubtedly improve the standard of education. According to Gene and Stoneman (1995:569) the participation of parents in schools indeed has a positive influence on the academic achievement of their children. The children's self-discipline and their eventual potential income could also benefit from their parents' positive participation. 


\subsection{Non-academic activities}

\section{Table 3: Non-academic activities}

\begin{tabular}{|l|l|l|l|}
\hline & $\begin{array}{l}\text { No } \\
\text { activity }\end{array}$ & $\begin{array}{l}\text { Little } \\
\text { participation }\end{array}$ & $\begin{array}{l}\text { Good } \\
\text { participation }\end{array}$ \\
\hline \hline Assist with extramural activities & $25.7 \%$ & $55.8 \%$ & $18.5 \%$ \\
\hline $\begin{array}{l}\text { Assist with the maintenance and } \\
\text { building of the physical facilities } \\
\text { of the school }\end{array}$ & $18.8 \%$ & $49.7 \%$ & $31.5 \%$ \\
\hline
\end{tabular}

\subsubsection{Findings and recommendations}

According to the teachers involved in the study, the participation of parents in non-academic school activities is slightly better than in the area of teaching and education. Teachers spend a lot of time on these activities at the expense of academic-related activities. Active parental participation in out-of-the-class activities can assist teachers tremendously and enable them to spend more time on academic work. Parents can be involved in coaching or training learners in extramural activities and they can for example be responsible for the maintenance and upgrading of the school buildings.

Involvement of parents in non-academic activities can be readily improved via the parent-teacher association or via committees of the governing body. The available skills and competencies of parents in these areas should be put to the best possible use. The parent-teacher association could compile a list of the skills that parents have to offer, and it will be possible to call on specific persons if a specific task, for example a painting job, needs to be done.

\subsection{Attending organised activities}

\section{Table 4: Aftending organised activities}

\begin{tabular}{|l|l|l|l|}
\hline & No activity & $\begin{array}{l}\text { Little } \\
\text { participation }\end{array}$ & $\begin{array}{l}\text { Good } \\
\text { participation }\end{array}$ \\
\hline $\begin{array}{l}\text { Attending parent evenings at the } \\
\text { school }\end{array}$ & $43 \%$ & $38 \%$ & $19 \%$ \\
\hline $\begin{array}{l}\text { Attending social events at the } \\
\text { school }\end{array}$ & $14.1 \%$ & $47.5 \%$ & $38.4 \%$ \\
\hline $\begin{array}{l}\text { Attending sport activities at the } \\
\text { school }\end{array}$ & $14.4 \%$ & $59.7 \%$ & $25.8 \%$ \\
\hline
\end{tabular}




\subsubsection{Findings}

The alarming aspect of the results pertaining to organised school activities is that it was found that many schools do not have regular parent evenings where parents can discuss their children's work with teachers or get information about the school. The participation of parents in sports and social activities was, however, found to be good.

It is important to note that parents were seen to be more involved in activities not related to academic activities or to the governance of the school. This could possibly be attributed to the fact that parents considered such areas "safer" in the sense that they did not require a high level of literacy and competency. Also, since parents' involvement in these areas did not have a substantial effect on the authority and academic work of the teachers, the latter allowed the parents to be more actively involved. The teachers probably did not feel threatened by the participation of parents in these activities.

\subsubsection{Recommendations}

Regular parent evenings can offer a very meaningful opportunity to improve the relationship and communication between home and school. This is especially true in the case of rural areas where other means of communication, such as telephones, are not readily available. Parent evenings must be the forum to initiate and promote the partnership idea.

Schools must use sports and social activities to improve their relationship with parents. In fact, sports and social activities can even be used to improve relationships in the community. Schools can and must be the centre of the community and they should therefore be used as such.

\subsection{Visits to and contact with the school}

\section{Table 5: Visits to and contact with the school}

\begin{tabular}{|l|l|l|l|}
\hline & $\begin{array}{l}\text { No } \\
\text { activity }\end{array}$ & $\begin{array}{l}\text { Little } \\
\text { participation }\end{array}$ & $\begin{array}{l}\text { Good } \\
\text { participation }\end{array}$ \\
\hline $\begin{array}{l}\text { Visit the school about academic } \\
\text { problems of their children }\end{array}$ & $8.9 \%$ & $69.2 \%$ & $21.9 \%$ \\
\hline $\begin{array}{l}\text { Visit the school only to criticise the } \\
\text { school (negative contact) }\end{array}$ & $25.9 \%$ & $50 \%$ & $24.1 \%$ \\
\hline $\begin{array}{l}\text { Only contact the teachers informal- } \\
\text { ly outside the school with school- } \\
\text { related problems }\end{array}$ & $15.8 \%$ & $59.7 \%$ & $24.6 \%$ \\
\hline
\end{tabular}




\subsubsection{Findings}

Parental involvement as described in the above circumstances can basically be classified as negative contact. Parents are fairly actively involved in visits to and contact with the school, and the considerable extent of such contact may indicate that there are many problems with learners' academic work and/or their behaviour.

\subsubsection{Recommendations}

Parental involvement in this category does not require any formal structures, since parents may visit or contact the school whenever they have a problem. Parents and teachers should, however, be encouraged to use these opportunities to communicate with each other. Schools must not only create opportunities for parents to voice their problems, but should also attend to such problems and try to solve them as soon as possible to prevent insignificant problems from becoming major ones.

\subsection{Conclusion}

In conclusion it can be stated that, in the opinion of the teachers involved in the study, parents are not adequately involved in school activities. The respondents rated parental participation in only two out of 14 activities as good. This is an indication that most parents neglect their mission to be involved in school activities.

Schools and families are functioning as sovereign entities in their own right but they are also involved with the other, because the same people are involved in both structures (Van der Walt et al., 1983:25). This makes it obligatory for the parents to be involved in school activities.

In general it may be deduced that the schools limit the participation and potential influence of parents, as this article indicates that in the case of each of the activities listed, there were schools that did not provide it. If no opportunities or structures exist, parents obviously cannot be involved, even if they would have liked to be involved. It is part of the mission of parents to be actively involved in school activities and therefore the schools and the parents must make a bigger effort to let parents be part of school activities.

\section{Reasons put forward by respondents for most black parents' lack of active participation in school activities}

According to the respondents the reasons why most black parents do not actively participate in the activities of the schools attended by their children can be divided into different categories. In their view, the reasons are - in order of priority from the most important to the least important - the following: 
- Parents' negative attitude towards the school.

- Parents' feelings of inferiority towards the teachers.

- Inadequate knowledge, skills and competencies of parents and teachers.

- Demographic reasons.

- Teachers' negative actions and attitudes

The percentages in the tables below indicate how important the respondent's rate the reasons why parents are not actively involved in the respective activities. It must be kept in mind that the parents did in fact participate in all the activities that were offered by the schools (cf. Tables 1-5 above). The discussion that follows will provide reasons why the respondents - a group of teachers believed those parents had not participated as positively and as actively as could be expected from them.

\subsection{Parents' negative attitude towards the school}

\section{Table 6: Negative attitude of parents towards the school}

\begin{tabular}{|l|l|}
\hline & $\%$ \\
\hline $\begin{array}{l}\text { Lack of responsibility for their children - parents think teachers } \\
\text { must take care of the children }\end{array}$ & 83,8 \\
\hline $\begin{array}{l}\text { Parents feel teachers should do the work because they get paid } \\
\text { for it }\end{array}$ & 83,1 \\
\hline $\begin{array}{l}\text { Parents do not know why they should participate in school } \\
\text { activities }\end{array}$ & 73,9 \\
\hline $\begin{array}{l}\text { Parents do not know that they are supposed to be involved in } \\
\text { school activities }\end{array}$ & 63,3 \\
\hline Parents are just not interested in school activities & 51,8 \\
\hline
\end{tabular}

This category indicates that, in the respondents' opinion, parents have a negative attitude towards their children's education and they do not feel responsible for it. The fact that parents feel that the teachers are qualified and salaried for this task probably reflects their feelings of inferiority when compared to the teachers. To worsen the situation, parents apparently do not even know that they must and can be involved in school activities, or how they can be involved. This attitude of parents - as perceived by the respondents - results in their neglecting their duty to be involved in the education of their children. 
Parents as partiners in black schools: so important, but why so unrellable?

Close to $74 \%$ of the respondents indicated that they believe parents to be ignorant of the fact that they should participate in school activities. This response implies inadequate communication between parents and the governing of schools

If the education authorities want parents to participate enthusiastically in school activities, they must show them what they (and the community at large) stand to gain from this partnership. This statement is even more true in some rural communities where parents would prefer their children to stay at home and work on the lands to earn money (Bhaerman \& Sciver, 1994:27). If parents, however, experience a positive outflow from their children's education, it is very likely that their attitude towards the school will change

Schools have to establish good relationships with the parents and the broader community to ensure effective education. Schools and parents are supposed to have the same culture and norms (Van der Westhuizen, 1997:407). This point of view indicates that there is no excuse for schools not to inform parents about their responsibilities to be involved in schools activities. Schools and parents must work together to improve this negative attitude.

\subsection{Feelings of inferiority towards the teachers}

\section{Table 7: Feelings of inferiority towards the teachers}

\begin{tabular}{|l|l|}
\hline & $\%$ \\
\hline $\begin{array}{l}\text { Parents of lower socio-economic status feel inferior and do not } \\
\text { participate in school activities }\end{array}$ & 73,5 \\
\hline $\begin{array}{l}\text { Parents regard themselves inferior to the teachers and principal } \\
\text { because the latter are academically better qualified }\end{array}$ & 59,2 \\
\hline
\end{tabular}

According to the respondents, parents feeling inferior to school staff and whoever does not have the necessary knowledge to participate meaningfully, cannot be effective partners. Illiteracy will further increase their feelings of inferiority. The above two categories of reasons for inadequate participation, namely a negative parental attitude and feelings of inferiority, are linked to the activities in which parents were the least involved, namely in the academic area. The research undertaken indicated that parents did not consider themselves capable of assisting the teachers, while the teachers indicated that most parents lacked the skills and knowledge to be effective assistants in the academic field 


\subsection{Knowledge and competencies of parents and teachers}

Table 8: Knowledge and competencies of parents and teachers

\begin{tabular}{|l|l|}
\hline & $\%$ \\
\hline $\begin{array}{l}\text { Parents feel that the teachers are trained and capable to manage } \\
\text { the school }\end{array}$ & 79.7 \\
\hline $\begin{array}{l}\text { Parents do not want to assist with academic work, because they } \\
\text { feel they are taking over the teachers' tasks }\end{array}$ & 65.5 \\
\hline $\begin{array}{l}\text { Parents do not have the skills and competencies to assist in } \\
\text { school activities }\end{array}$ & 50.0 \\
\hline Parents are illiterate and cannot communicate effectively & 37.5 \\
\hline
\end{tabular}

According to the respondents, the parents' experience that they do not have the skills to contribute meaningfully and that teachers are trained and therefore have more skills, increase their feelings of inferiority as well as their negative attitude towards the schools.

School staff must be sensitive to the fact that parents can be involved in school activities at different levels (Bauch, 1994:53-57). If parents do not have the required academic skills and knowledge for school management or teaching assistance, they can participate on the lower levels that require lower academic skills. Assisting children with homework and attending school functions do not require specific skills, but can indicate that the parents are dedicated to and positive about the school. Parents can assist teachers with sport or cultural activities, according to their specific talents.

\subsection{Demographic reasons}

Table 9: Demographic reasons

\begin{tabular}{|l|l|}
\hline & $\%$ \\
\hline \hline Parents do not stay near the school - work in other areas & 54,6 \\
\hline Parents do not have transport to the school & 34,6 \\
\hline
\end{tabular}


Although these reasons are not high on the list of important factors, they are more important in rural areas where parents do not have transport. Bhaerman and Van Schiver (1994:26) identify accessibility and transport problems as problems that obstruct effective education and parental participation in schools. Schools must organise their activities in such a way that parents have enough time to reach the school to attend such events and again to reach their homes after the conclusion of the activities. Parents must be notified of events at an early enough stage so as to enable them to make the necessary travel arrangements to attend. If at all possible, schools must provide transport or arrange with parents who can provide transport to fetch others and transport them to and from the school.

\subsection{Teachers' negative actions and attitudes}

\section{Table 10: Teachers' negative actions and attitudes}

\begin{tabular}{|l|l|}
\hline & $\%$ \\
\hline \hline $\begin{array}{l}\text { The school does not organise activities or opportunities for } \\
\text { parental involvement }\end{array}$ & 56,4 \\
\hline $\begin{array}{l}\text { There is not effective communication with the parents - they do } \\
\text { not know about school activities }\end{array}$ & 52,6 \\
\hline The principal does not encourage parents to become involved & 45,0 \\
\hline Teachers do not want parents to be involved in school activities & 13,5 \\
\hline
\end{tabular}

This is the category that had the lowest rating as possible reasons why parents do not actively participate in school activities. The low rating of this category also does not correlate with the information in paragraph 4 , where the overall participation level of parents in the indicated activities was said to be low. The fact that some of activities did not even exist at most schools could well mean that schools do not make provision for structures or opportunities of parental participation. Parents' low level of participation, even where structures or opportunities were available for participation, could indicate that the schools did not adequately encourage parents to get involved, or perhaps even that teachers did not want the parents to be actively involved in school activities.

It must once again be kept in mind that the questionnaire on which this survey is based was completed by a group of teachers. Therefore, if the teachers indicated that the school was a major reason for the non-participation of parents in school activities, it could reflect very unfavourably on the teachers themselves. 


\section{Conclusion}

Although the respondents in this research were teachers, the results coincide with the results of the research of Khan (1996:62). Khan's research includes the view of parents and he provides the same reasons why parents are not actively involved in school activities.

Although the research underlying this article indicate that black parents in many instances neglect their mission to be part of the education of their children, the cultural factors and the situations in the communities where the people live and work must be taken into account. Parents in black communities do not have a tradition of involvement in school activities. Although they may have the needs to participate in school activities and are willing to co-operate with the schools, schools must provide the opportunities and structures for parents to enable them to participate positively.

The participation of black parents in school activities is very poor. According to the research undertaken the governing body is the only activity in which parents are taking part to a satisfying extent - perhaps because the governing body is the only legally structured body in which parents are obliged to participate. In terms of the South African Schools Act of 1996, the principal, teachers and parents do not have a choice but to participate and work together as partners in this structure. The results of the research however indicate that only $57 \%$ of the schools experienced good participation from their parents in the governing body.

According to the results of the study undertaken there is - at this stage - no evidence of an effective partnership between parents and schools, despite the fact that parents as their children's primary educators can rightfully be expected to be actively involved in the activities arranged by the school.

Schools, and especially principals, must take note of the reasons why parents are not actively involved in school activities. They have to plan and manage the situation so as to improve it to the benefit of both parties. Being involved in school activities may cause parents to change their own attitude towards the school, as well as that of their children, which may again lead to better examination results by the learners. According to Stone (1995:798), a school in a poor, multicultural area indeed changed for the better after parents had become active partners of the school and really involved themselves with school activities.

\section{Recommendations}

Further studies should focus on specific areas that need more intensive research in order to provide more specific solutions. Such research may be particularly important for specific types of schools, schools in specific geographical areas or for specific school activities. 


\section{References}

BAUCH, J P. 1994. Categories of parent involvement. The School Community Joumal, 4(1):53-60

BHAERMAN, R. \& VAN SCIVER, J. 1994. Voices of the rural community in deliberating educational goals Rural Educator, 15(2) 25-30

EPSTEIN, J.L 1996. Advances in family, community and school partnerships. New School, New Communities, 12(3):5-13.

GENE, H.B. \& STONEMAN, Z. 1995 Linking family processes and academic competence among nural African American youth. Journal of Marriage and the Family, 57(3):567579

HENNING, E. \& FOURIE, E. 1997. Community and school: Leaming beyond the curriculum. South African Journal of Education, 17(3):116-124.

HEYSTEK, J 1998. Empirical research: Parental involvement in school activities. Pretoria University of Pretoria. Unpublished research report

KHAN, M B. 1996. Parental involvement in education: Possibilities and limitations. The School Community Journal, 6(1):57-68.

MAVHIVA, E. 1996. The relationship between school and community among selected schools in the Northern Transvaal Province. Pretoria : UP. (M.Ed. Dissertation.)

SCHOEMAN, P.G. 1980. An introduction to a Philosophy of Education. Pretoria : Butterworths.

STONE, C.R. 1995. School/community collaboration. Comparing three initiatives. Phi Delta Kappan, 76(2):974-800.

SUND, R.B. 1976. Piaget for educators Ohio : Merrill

VAN DER WALT, J.L. 1992. Opvoeding en onderwys: vennootskap tussen Christelike ouerhuis, kerk en skool veral gesien vanuit die hoek van die skool. (Education and teaching: Partnership between the Christian home, church and school, viewed especially from the school's angle). South African Journal of Education, 12(2):226-229.

VAN DER WALT, J.L., DEKKER, E.I \& VAN DER WALT, ID 1983. Die Opvoedingsgebeure. 'n Skrifmatige perspektief. Pretoria : Mortimer.

VAN DER WESTHUIZEN, P C. 1996. Schools as organisations. Pretoria : Van Schaik

VAN DER WESTHUIZEN, P C. 1997. Effective educational management. Pretoria : Kagiso Tertiary.

WOLFENDALE, S 1992. Empowering parents and teachers. Working for children. London : Cassell 